\title{
Definition of a Global Stratotype Section and Point (GSSP) for the base of the Upper (Late) Pleistocene Subseries (Quaternary System/Period)
}

\author{
1 Steinmann Institute for Geology, Mineralogy and Palaeontology, University of Bonn, Germany.E-mail: t.litt@uni-bonn.de \\ 2 Godwin institute of Quaternary Research, Department of Geography, University of Cambridge, Downing Street Cambridge CB2 3EN, \\ England.E-mail:plg1@cam.ac.uk
}

Following the precedence already established during the INQUA Congress in 1932, the Middle/Upper (Late) Pleistocene boundary is defined at the base of the Last Interglacial, the Eemian Stage. It is proposed that a high-resolution core sequence from the Amsterdam Terminal (the Eemian Stage parastratotype) should constitute the Global Stratotype Section and Point (GSSP) for the base of the Upper (Late) Pleistocene Subseries (Quaternary System/Period). The core contains a proxy climate record across the Middle/Upper (Late) Pleistocene boundary as indicated by different biotic and abiotic parameters reflecting the first signs of climate warming at the end of the Saalian cold Stage. For the beginning of the Eemian Stage in Europe, the date of $127.2 \mathrm{ka}$ from the varved-dated record of Monticchio in Italy can be taken as the best estimate of age.

\section{Boundary stratotype-state of the art}

The basic principles used in subdividing the Pleistocene as a Series into chronostratigraphical units are the same as for other Phanerozoic units which require boundary definitions and the designation of boundary stratotypes (Salvador, 1994). However, in contrast to the rest of the Phanerozoic, the division of Quaternary sequences on the basis of climatic changes documented in the sedimentary record is fundamental and has a long tradition. Classifications based on climatostratigraphical units are reasonably well-established in different countries, or areas and are accepted as regional chronostratigraphical standards (Gibbard and West, 2000, Gibbard and van Kolfschoten, 2004)

In terms of the subdivision of the Pleistocene, a quasiformal tripartite classification into Lower (Early), Middle and Upper (Late) Pleistocene as a subseries is generally used. The boundary between the Middle and Upper Pleistocene has not yet been formally defined by IUGS. However, already during the 2nd INQUA Congress in Leningrad in 1932 the decision was made to define the Middle/Upper (Late) Pleistocene boundary at the base of the Last Interglacial, the Eemian Stage (Woldstedt, 1962). Both the Last Interglacial and the Last Glacial (Weichselian, Würmian, Wisconsinan, Valdaian and equivalents) are considered to be included into the Upper (Late) Pleistocene (Figure 1). More recently the lower boundary of the Upper (Late) Pleistocene has been placed at the base of Marine Isotope Stage 5 (MIS 5) by Richmond (1996) based on a proposal of the INQUA Subcommission on Stratigrahy (unpublished). This proposal followed the view that the MIS 5e Substage in the ocean sediments is equivalent to the northwest European Eemian Interglacial Stage on land (Shackleton, 1977). Although it may seem attractive to define the boundary in an ocean-sediment sequence, the inherent imprecision of most of such sequences, resulting from slow sedimentation rate, combined with the effects of bioturbation, suggests that for high-resolution stratigraphical purposes they are generally unsuitable for the definition of 'golden spike'-type, 'time-plane' boundaries. In addition, the direct comparison between terrestrial pollen, benthic/planktonic foraminifera and isotopes from the same deep-sea core west of Portugal shows that temperature changes are not in phase with ice volume variations (Figures 1 and 3). Pronounced offsets between marine isotopic warm stages boundaries and forested intervals were described by Sánchez Goñi et al. (1999) for MIS 5 (see below). To obviate this problem, following the precedence established 75 year ago, Gibbard (2003) proposed that the Middle/Upper Pleistocene boundary stratotype (the Global Stratotype Section and Point-GSSP) should be defined in the newlyprocessed high-resolution core sequence from the Amsterdam-Terminal (the Eemian Stage parastratotype, cf. van Leeuwen et al. 2000, see Figure 2). This proposal is currently under examination by a working group of the International Subcommission on Quaternary Stratigraphy.

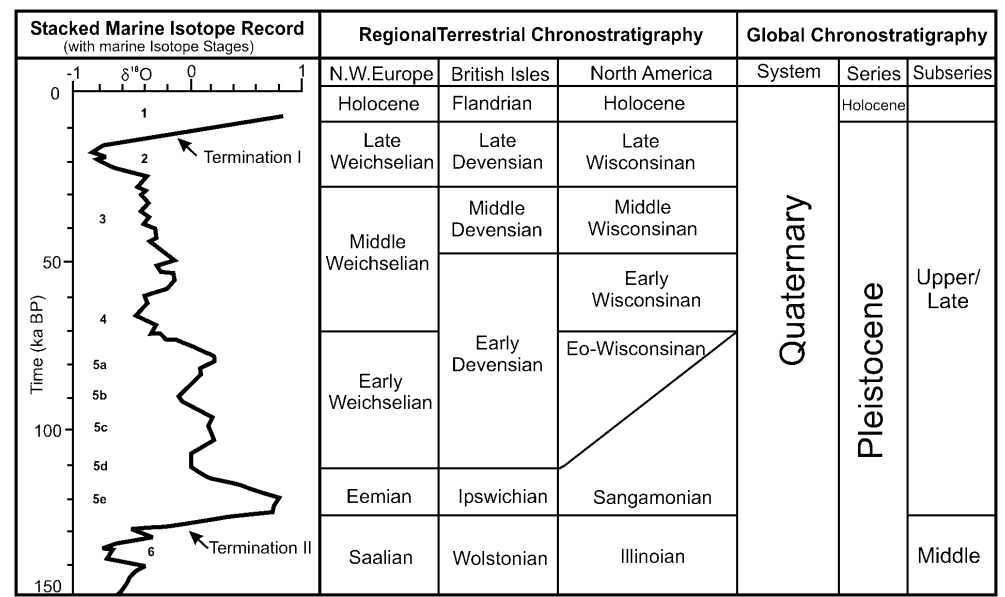

Figure 1 Marine and continental chronostratigrahy for the past $150 \mathrm{kyr}$. The stacked marine oxygen isotope sequence and associated stages are from Martinson et al. (1987). (Modified after Gibbard and van Kolfschoten, 2004.) Note that the MIS 6/5e boundary (Termination II) have been significantly earlier than the Saalian/Eemian stage boundary on land (see also Figure 3). A similar pronounced offset between marine isotopic warm stage boundary 2/1 (Termination I) and the Plesitocene/Holocene boundary occurs. 


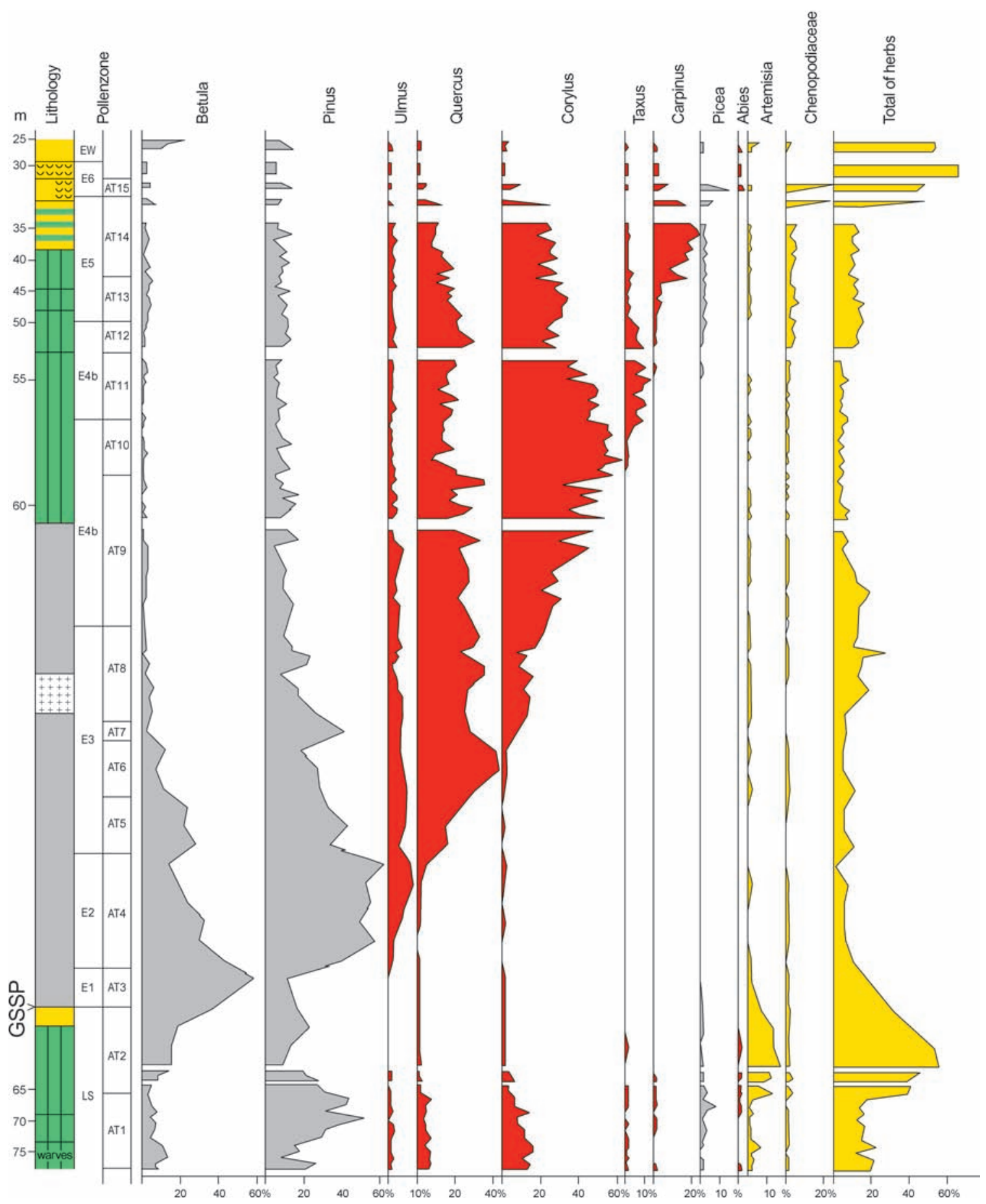

Figure 2 Amsterdam-Terminal borehole (the Netherlands) and pollen assemblages. The proposed stratotype boundary horizon is based on the steep rise of the Betula pollen curve at this point (after van Leeuwen et al. 2000).

\section{Correlation on land}

The proposed stratotype boundary horizon in the Amsterdam Terminal borehole is based on the steep rise of the Betula pollen curve at this point (Figure 2). A similar rise in the Betula curve can be seen in Eemian Interglacial pollen diagrams from England, across the North European plain to Poland and Russia in shallow marine, as well as terrestrial sediment sequences (Menke and Tynni 1984, Turner 2002). Representative sites that show this horizon include Gröbern in central Germany (Litt et al., 1996), Imbramowice in Poland (Mamakowa 1989) and Cheremoshnik in the Rostov Veliky region of Russia (Velichko et al. 2005).
The argument for regarding this horizon at which Betula expanded as being more or less synchronous, within the limits of precision for defining a stratotype during this time interval, are twofold. Firstly, the expansion of the Betula pollen curve is seen as a vegetational response to climatic amelioration, with tree-birches beginning to form woodland communities in response to increased solar radition and the renewed influence of the warm waters of the revived North Atlantic currents that affected not just the western coastlands of Europe but the whole climate of northern Eurasia even beyond the Ural mountains to Central Asia. The second relies on comparisons with events at the end of the last glacial stage (Weichselian, Würmian, Valdaian, Wisconsinan). Evidence relating to the Late Weichselian Younger Dryas Stadial-Holocene transition sug- 


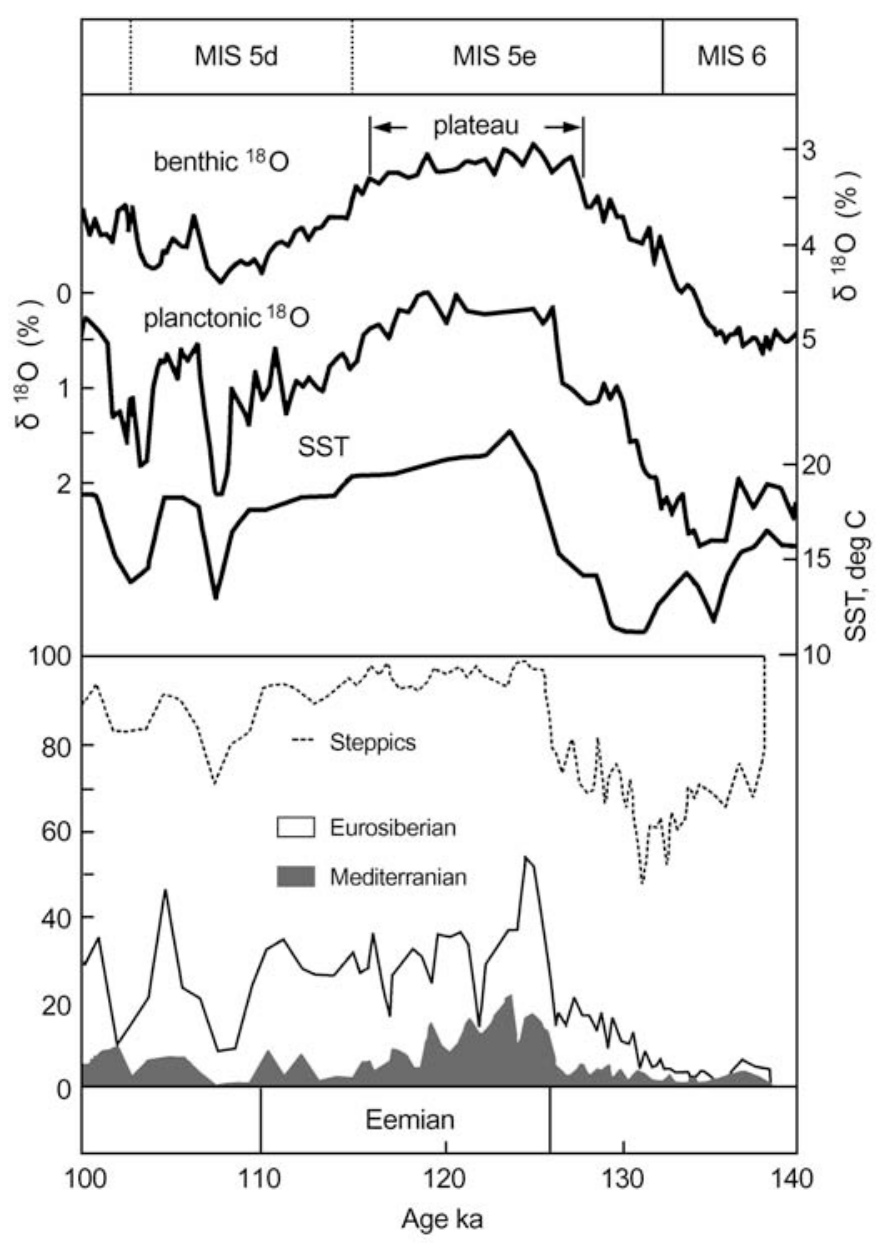

Figure 3 Marine and continental records of the last interglacial in core MD95-2042 (west of Portugal). The MIS 6/5e boundary differs significantly to those of the Saalian/Eemian stage boundary on land identified by pollen analysis of the marine sedi-ments (after Shackleton et al., 2002).

gests that the expansion of tree-birches was almost synchronous at that time (even perhaps within a matter of decades) across this whole region (Litt et al., 2001, 2003). The same arguments are used in attempting correlation with pollen sequences from southern Europe, where evidence is available both from Atlantic marginal cores west of Portugal (Sanchez-Goñi et al., 1999) and from a number of deep lake basins in the Mediterranean region (Brauer et al., 2007, Follieri et al., 1988; Tzedakis, 1994; Wijmstra and Smit, 1976). Sites in the French Massif Central (Reille et al., 1998; de Beaulieu and Reille, 1992) provide an intermediate situation between northern Europe and the Mediterranean. At these sites the horizon corresponding to the stratotype boundary horizon in the Netherlands is seen as being marked by a major expansion of forest trees, in particular by the rise of the pollen curve of Quercus, but perhaps most markedly the abrupt collapse of the pollen curves of steppic taxa such as Artemisia and Chenopodiaceae. Here again the interpreted vegetational changes are so intense and abrupt that they must be a response to a powerful climatic signal, assumed to be the same combination of increasing solar radiation and Atlantic circulation changes that relate to the vegetation changes used to define the stratotype horizon in the Netherlands.

Because the onset of the Last Interglacial forest expansion in southern and northern Europe appears to be relative synchronous (Tzedakis, 2003), for the beginning of the Eemian in the entire Europe the date of 127,2 ka from the varved-dated record of Monticchio (Brauer et al., 2007) can be chosen as a direct geochronological tie-point based on a calendar-year time scale.

\section{Land-sea correlation}

Of particular importance for Pleistocene stratigraphy are the essentially time-parallel periods of rapid climate change termed 'terminations' (Broecker and van Donk, 1970), seen in ocean sediment oxygen isotope sequences. The major, dramatic changes in world icevolume so indicated, imply climate shift from full-glacial to interglacial conditions over short timespans of a few millenia that may appear as 'abrupt' events at commonly-used graphic scales. In favourable situations, these sharp changes can also be recognized on land as dramatic changes in pollen assemblage composition or other parameters; for example where sufficiently long and detailed sequences are available, such as in long lake cores (cf. Tzedakis et al., 1997). It may then, on face-value, seem attractive to attempt to use such termination events as a potential means for land-sea correlation. However, their value for correlation may be limited in high sedimentation-rate sequences because the 'terminations' are not instantaneous, but represent several thousand years (Broecker and Henderson, 1998). These matters clearly concern questions of resolution and scale.

Termination II marks the major shift immediately before MIS 5 , the change thought to represent the climatic event represented by the Saalian-Eemian (and equivalents) stage boundary in NW Europe. Martinson et al. (1987) calculated the date of the base of MIS 5 at c. 130 ky B.P., i.e., corresponding to the end of Termination II of the marine oxygen isotope sequences (Broecker and Van Donk, 1970). More recently the mid-point of Termination II was recalculated to $128 \mathrm{ky}$; the amelioration beginning at $132 \mathrm{ky}$ and ending 6 ky years later at $126 \mathrm{ky}$, based on data from a series of high-resolution ocean core profiles (Broecker and Henderson, 1998). On this basis the Last Interglacial duration would be 129-119 ky, based on use of mid-points for defining MI stage or substage boundaries, according to Broecker and Henderson (1998).

The precise recognition and timing of boundaries or events from the ocean sediment (MI) stages on land and vice versa is of great concern for the development of a fully-integrated, high-resolution terrestrial-marine global stratigraphy. However, the differing rates and ways that different proxies respond to climate changes and these changes themselves may be multifactoral and time-transgressive. That boundaries defined using different proxies do not necessarily invariably occur at the same time has been graphically demonstrated by the work west of Portugal by Sanchez-Goñi et al. (1999) and Shackleton et al. (2002). Here the MIS 6/5e boundary has been shown to have been significantly earlier than the Saalian / Eemian stage boundary on land identified by pollen analysis of the marine sediments (Figure 3). The Eemian interglacial (sensu stricto) must coincide only with the lightest isotopic values of Substage 5e beginning at $126 \mathrm{ky}$. Thus if high-resolution terrestrial sequences and lowresolution marine sequences are to be correlated accurately, one clearly cannot assume that the boundaries recognized in these very different environmental situations are indeed coeval (cf. Gibbard and West, 2000, Gibbard, 2002).

A similar problem arises for the Italian marine stage nomenclature in which the term Tarantian was proposed over ten years ago (Cita and Castradori, 1994;1995; van Couvering, 1995) for the interval from the MIS $6 / 5$ boundary or Termination II to the base of the Holocene (Cita this volume). For reasons of internal consistency and heirarchy, the basal boundary of both this stage and that of the Upper (Late) Pleistocene Subseries must coincide.

\section{References}

Brauer, A., Allen, J.R.M., Mingram, J., Dulski, P., Wulf, S., and Huntley, B. 2007, Evidence for last interglacial chronology and environmental change from Southern Europe: PNAS, v. 104, pp, 450-455.

Broecker, W.S., and Henderson, G.M., 1998, The sequence of events surrounding Termination II and their implications for the cause of glacialinterglacial CO2 changes: Paleooceanography, v. 13, pp. 352-364. 
Broecker, W.S., and Van Donk, J., 1970, Insolation changes, ice volumes and the 180 record in deep-sea cores: Review of Geophysics and Space Physics, v. 8, pp. 169-198.

Colhoun, E.A., Pola, J.S., Barton, C.E., and Heijnis, H., 1999, Late Pleistocene vegetation and climate history of Lake Selina, western Tasmania: Quaternary International, v. 57/58, pp. 5-23.

Cita, M.B., 2008, Summary of Italian marine stages: Episodes, this volume.

Cita, M.B., and Castradori, D., 1994, Workshop on marine sections of Gulf of Taranto (Southern Italy) usable as potential stratotypes for the GSSP of the Lower, Middle and Upper Pleistocene: Il Quaternario, v. 7, pp. 677-692.

Cita, M.B., and Castradori, D., 1995, Rapporto sul Workshop "Marine sections from the Gulf of Taranto (Southern Italy) usable as potential stratotypes for GSSP of the Lower, Middle and Upper Pleistocene": Bollettino della Società Geologica Italiana, v.114, pp. 319-336.

De Beaulieu J.-L., and Reille, M., 1992, Long Pleistocene pollen sequences from the Velay Plateau (Massif Central, France). I. Ribains maar : Vegetation History and Archaeobotany, v. 1, pp. 233-242.

Follieri, M., Magri, D., and Sadori, L., 1988, 250,000-year pollen record from Valle di Castiglione (Roma): Pollen et Spores, v. 30, pp. 329-356.

Gibbard, P.L., 2003, Definition of the Middle-Upper Pleistocene boundary: Global and Planetary Change, v. 36, pp. 201-208.

Gibbard. P. L., and van Kolfschoten, T., 2004, The Pleistocene and Holocene Epochs, in Gradstein, F., Ogg, J., and Smith, A., eds, A Geologic Time Scale 2004: Cambridge, Cambridge University Press, pp. 441-452.

Gibbard, P.L., and West, R.G., 2000, Quaternary chronostratigraphy: the nomenclature of terrestrial sequences, Boreas, v. 29, pp. 329-336.

Litt, T., Brauer, A., Goslar, T., Merkt, J., Balaga, K., Müller, H., RalskaJasiewiczowa, M., Stebich, M., and Negendank, J.F.W., 2001, Correlation and synchronisation of Lateglacial continental sequences in northern central Europe based on annually laminated lacustrine sediments: Quaternary Science Reviews, v. 20, pp. 1233-1249.

Litt, T., Junge, F.W., Böttger, T., 1996, Climate during the Eemian in northcentral Europe - a critical review of the palaeobotanical and stable isotope data from central Germany: Vegetation History and Archaeobotany, v. 5 , pp. $247-256$.

Litt, T., Schmincke, H.-U., and Kromer, B., 2003, Environmental response to climate and volcanic events in central Europe during the Weichselian Lateglacial: Quaternary Science Reviews, v. 22, pp. 7-32.

Mamakowa, K., 1989, Late Middle Polish glaciation, Eemian and Early Vistulian vegetation at Imbramowice near Wroclaw and the pollen stratigraphy of this part of the Pleistocene in Poland: Acta Palaeobotanica, v. 29, pp. 11-176.

Menke, B., and Tynni, R., 1984, Das Eeminterglazial und das Weichselfrühglazial von Rederstall/Dithmarschen und ihre Bedeutung für die mitteleuropäische Jungpleistozän-Gliederung: Geologisches Jahrbuch, v. A 76 , pp. $3-120$

Martinson, D.G., Pisias, N.G., Hays, J.D., Imbrie, J., Moore, T.C., and Shackleton, N.J., 1987, Age dating and the orbital theory of the ice ages: development of a high-resolution0 to 300000 year chronostratigraphy: Quaternary Research, v. 27, pp. 1-29.

Reille, M., Andrieu, V., de Beaulieu, J-L., Guenet, P., and Goeury, C., 1998, A long pollen record from Lac du Bouchet, Massif Central, France: for the period ca. 325 to $100 \mathrm{ka}$ (OIS 9c to OIS 5e): Quaternary Science Reviews, v. 17, pp. 1107-1123

Richmond, G.M., 1996, The INQUA-approved provisional Lower-Middle Pleistocene boundary, in Turner, C. ed, The early Middle Pleistocene in Europe: Rotterdam, Balkema, pp. 319-326.

Salvador, A., ed, 1994, International Stratigraphic Guide: A guide to stratigraphic classification, terminology, and procedure. 2nd edition, International Union of Geological Science / Geological Society of America Trondheim, Boulder, $214 \mathrm{pp}$.

Sanchez-Goñi M.F., Eynaud, F., Turon, J.L. and Shackleton, N.J., 1999. High resolution palynological correlation off the Iberian margin: direct land-sea correlation for the Last interglacial complex: Earth and Planetary Science Letters, v. 171, pp. 123-137.

Shackleton, N.J., 1977, The oxygen isotope stratigraphic record of the Late Pleistocene: Philosophical Transactions of the Royal Society of London, B 280, p. 169-182.

Shackleton, N.J., Chapman, M., Sanchez-Goñi, M.F., Pailler, D., and Lancelot, Y., 2002, The classic Marine Isotope Substage 5e: Quaternary Research, v. 58, pp. 14-16.

Turner, C., 2002, Formal Status and Vegetational Development of the Eemian Interglacial in Northwestern and Southern Europe: Quaternary Research, v. 58, pp. 41-44.

Tzedakis, P.C., 1994, Vegetation change through glacial-interglacial cycles: a long pollen sequence perspective: Philosophical Transactions of the Royal Society of London, v. B 345, pp. 403-432.

Tzedakis, P.C., 2003, Timing and duration of Last Interglacial conditions in Europe: a chronicle of a changing chronology: Quaternary Science Reviews, v. 22, pp. 763-768.
Tzedakis, P.C., Andrieu, V., Beaulieu, J.L. de, Crowhurst, S., Follieri, M. Hooghiemstra, H., Magri, D., Reille, M., Sadori, L., Shackleton, N.J. and Wijmstra, T.A., 1997, Comparison of terrestrial and marine records of changing climate of the last 500000 years: Earth and Planetary Science Letters, v. 150, pp. 171-176.

Van Couvering, J.A., 1995, Setting Pleistocene Marine Stages: Geotimes, v. 40 , pp. $10-11$

Van Leeuwen, R.J.W., Beets, D.J., Bosch, J.H.A., Burger, A.W., Cleveringa, P., van Harten, D., Herngreen, G.F.W., Kruk, R.W., Langereis, C.G., M., T., Pouwer, R., and de Wolf, H., 2000, Stratigraphy and integrated facies analysis of the Saalian and Eemian sediments in the Amsterdam-Terminal borehole, the Netherlands: Geologie en Mijnbouw, v. 79, pp. 161-196.

Velichko, A.A., Novenko, E.Y., Pisareva, V.V., Zelikson, E.M. Boettger, T., and Junge, F.W. 2005, Vegetation and climate changes during the Eemian interglacial in Central and Eastern Europe: comparative analysis of pollen data: Boreas, v. 34, pp. 207-219.

Wijmstra, T.A., and Smit, A., 1976, Palynology of middle part (30-78 meters) of 120 deep section in northern Greece (Macedonia): Acta Botanica Neerlandica, v. 25, pp. 297-312.

Woldstedt, P., 1962, Über die Benennung einiger Unterabteilungen des Pleistozäns: Eiszeitalter und Gegenwart, v. 3, pp. 14-18.

Thomas Litt is professor of palaeobotany at the University of Bonn, Germany. He studied prehistory, geology and botany and received the doctoral as well as the habilitation degree (venia legendi) in geology. His research interests include the palaeoecology, palaeoclimate and stratigraphy of the Quaternary. He has been involved in several research programs dealing with high-resolution annually laminated lacustrine sediments in Eurasia. Thomas Litt was chairman of the German Subcommision on Quaternary Stratigraphy (2000-2007) and is voting member of the Subcommission on Quaternary Stratigraphy of the IUGS. He is the current President of the International Federation of Palynological Societies.

Philip Gibbard is Professor of Quaternary Palaeoenvironments at the University of Cambridge, United Kingdom, and chair of the International Commission on Stratigraphy's Subcommission on Quaternary Stratigraphy. He is also a member, and was formerly Secretary, of the Stratigraphy and Geochronology Commission of INQUA, the INQUA Subcommission of European Quaternary Stratigraphy and the Geological Society of London's Stratigraphy Commission. His research is focused on terrestrial and shallow marine sedimentation, stratigraphy and environmental evolution throughout Europe, but he has also worked in the Arctic, North America and South-East Asia.
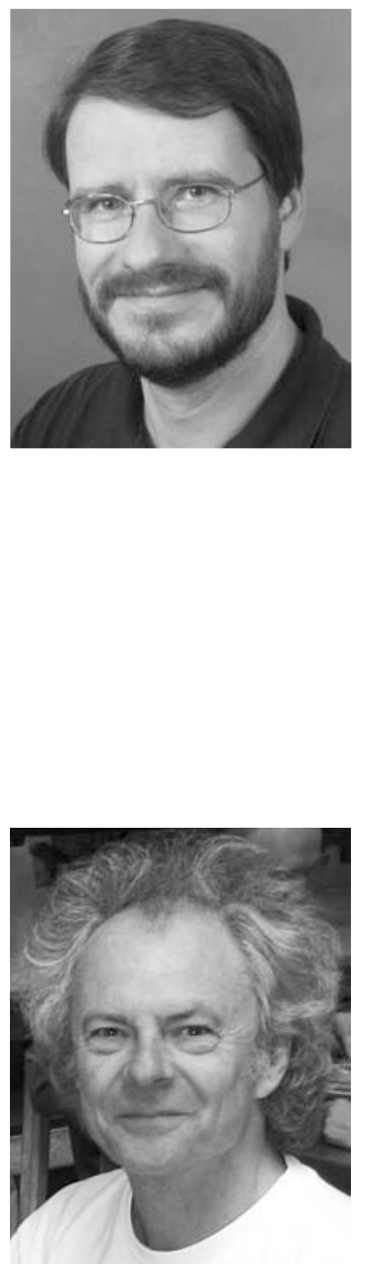